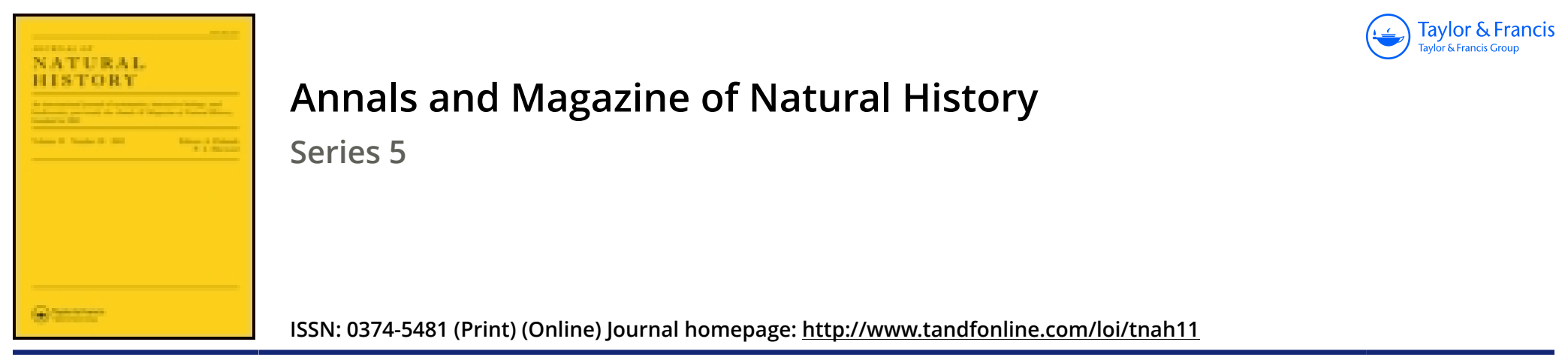

\title{
XL.-On the species of Ocypoda in the collection of the British Museum
}

\section{Edward J. Miers F.L.S. F.Z.S.}

To cite this article: Edward J. Miers F.L.S. F.Z.S. (1882) XL.-On the species of Ocypoda in the collection of the British Museum , Annals and Magazine of Natural History, 10:59, 376-388, DOI: 10.1080/00222938209459729

To link to this article: http://dx.doi.org/10.1080/00222938209459729

$$
\text { 册 Published online: } 07 \text { Oct } 2009 .
$$

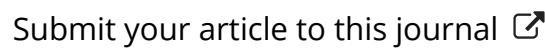

Џ Article views: 3

Q View related articles $\sqsubset$

4 Citing articles: 2 View citing articles 진 
Mr. Moore has Burmese specimens of this species in his cabinet with $E$. bellona.

Captain Bingham also took E. excubitor in the Thoungyeen valley on the 25th February.

\section{XI.-On the Species of Ocypoda* in the Collection of the British Museum. By EDward J. Miers, F.L.S., F.Z.S., Assistant in the Zoological Department.}

[Plate XVII.]

Having had occasion to rearrange and rename the specimens of this genus in the collection of the British Museum, with the aid of Mr. J. S. Kingsley's recently published revisiont, I have thought it would be useful to publish the following notes on the species represented in the national collection (among which are included nearly all the well-established ones), to indicate at the same time the few which are desiderata, and to describe and figure with more precision than has been hitherto done their principal distinctive characters, especially such as are afforded by the form of the antero-lateral angle of the carapace (or exterior orbital angle) and by the structure of the stridulating-ridge, which is developed apon the inner surface of the palm or penultimate joint of the larger chelipede in nearly all the species, and to which particular attention has been drawn by Dr. J. G. De Man in his careful account of the species in the collection of the Leyden Museum:.

In this memoir certain forms are characterized which are not included in the revision of the American naturalist, whose material seems to have been insufficient for the correct identification of some of the Old-World species.

In the following notes I have usually followed De Man pretty closely in his definitions (so far as they serve); and I

* This generic name has been variously written Ocypoda and Ocypode by authors. I myself formerly adopted the latter; but perhaps the foriner mode of spelling the word (although not that of Fabricius) is preferable, as being etymologically more correct. It would be merely productive of additional contusion to adopt (as I have been advised) Ocypus in place of either, since this word has been used by a later author (Kirby, in 1819) for a genus of Coleoptera.

$\dagger$ "Revision of the Genus Ocypoda," in Proc. Acad. Nat. Sci. Philad. pp. 179-186 (1880).

$\ddagger$ Notes from the Leyden Museum, iii. pp. 245-256 (1881). 
Ann. \& Mag. Nat. Hist. S. 5. Vol. 10. Pl. XVII

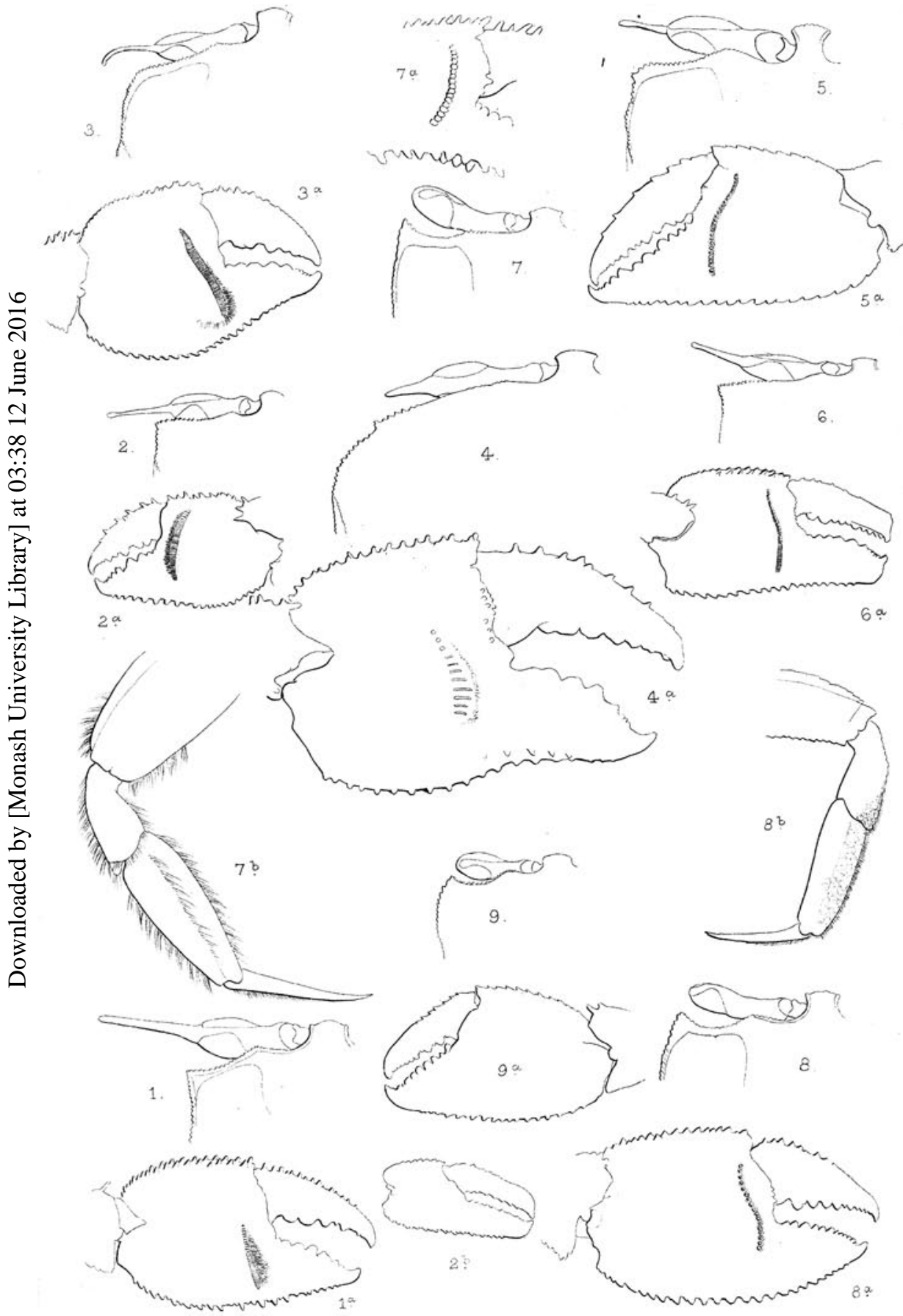


have not thought it necessary to reproduce the synonymical references which have already been given by Kingsley.

For the correct identification of a species of Ocypoda it is necessary to have adult examples, since the characters are subject to great variation or are even totally lost in younger specimens, on which I doubt not several of the nominal species characterized by former authors have been founded. Even Mr. Kingsley, extensive as are his synonymical citations, has probably admitted two or three which an examination of the types would show to have been established upon insufficient grounds.

I admit in all ten apparently well-established species, and also one species ( $O$, africana, De Man) which I must regard as of doubtful permanence, but which is not at present represented in the British-Museum collection. Of these species four (O. regyptiaca, O. rotundata, $O$. Kuhlii, and $O$. africana) are not included in Kingsley's report; but $O$. rotundata and $O$. africana were not described at the time of its publication. On the other hand, Mr. Kingsley admits three species (O. Urvillei, Guérin, O. convexa, Quoy and Gaimard, and $O$. Ryderi, Kingsley) on, as it seems to me, insufficient grounds; but of $O$. Ryderi I have seen no specimens, and this species is, moreover, but very briefly characterized.

Of the species referred to in the following notes, three (Ocypoda ceratophthalma, $O . K u h l i i$, and $O$. cordimana) are widely distributed through the Oriental region; $O$. cursor occurs on the coasts of the Mediterranean and also in the Red Sea (Heller), and at the Canaries, Cape-Verds, and on the WestAfrican coasts southward to Acra d'Elmina; $O$. arenaria ranges along the east American coast from New Jersey southward to Rio de Janeiro, Brazil ; O. Gaudichaudii along the western coast of the same continent from Panama to Chile; $O$. cogyptiaca occurs on the Red-Sea coasts and also at Nossy Faly, Madagascar (Hoffmann) ; O. rotundata is only known from the west coast of India; $O$. macrocera and $O$. platytarsis occur on the coasts of India ( $O$. platytarsis also at Ceylon), and both species are also recorded by Heller from the Nicobars and Tahiti. O. africana, De Man (a species which I have not seen, but must regard as doubtfully distinct from $O$. Kuhlii), is found on the coasts of Liberia and the Congo.

Some other localities given for certain, species are probably erroneous, as (e.g.) Brazil for O. macrocera, mentioned by Milne-Edwards in his earlier but not in his later account of the genus *.

* See Hist. Nat. Crustacés, ii. p. 49 (1837); Ann. Sci. Nat. sér. 3, xriii. p. 142 (1852). 
Kingsley mentions the occurrence of $O$. arenaria on the west coast of Mexico (t.c. p. 185); but I think it possible that the specimens from this locality should be referred to O. Kuhlii, var. occidentalis, Stimpson. In the following notes the names in brackets which follow the localities are, with few exceptions, the names of the donors (and not necessarily the collectors) of the specimens in the Museum collection.

The principal characters separating the species of Ocypoda may be briefly tabulated as follows:-

I. Ocular peduncles prolonged beyond the cornea as a spine or style.

A. The terminal style tipped with a pencil of hairs.

Stridulating-ridge finely striated .... O. cursor (Linn.).

B. The terminal style without hairs at apex.

* Fingers of both chelipedes acute.

Sides of the carapace straight behind the rather acute orbital angles. Stridulating-ridge coarsely striated above, finely striated below. .

Sides of carapace slightly arcuated behind the scarcely acute anterolateral angles. Stridulating-ridge finely striated throughout ......

Sides of carapace strongly arcuated; antero-lateral angles obsolete. Stridulating-ridge developed only in its lower portion, and the stria separated by very wide intervals. O. ceratophthalma (Pallas).

Carapace broader, with the sides straight behind the acute anterolateral angles. Stridulating-ridge narrow, tuberculate throughout. .

* Fingers of the smaller chelipede dilated at the distal extremity.

Stridulating-ridge ratherbroad,finely

and evenly striated ..............
** Fingers of both chelipedes dilated and
truncated at the distal extremity. o. agyptiaca, Gerstäcker.

Stridulating-ridge narrow, tuberculated above, striated below ....

II. Eyes rounded at the distal extremity, O. macrocera, M.-Edw.

O. rotundata, Miers.

O. platytarsis, M.-Edw.

O. Gaudichaudii, M.-Edw. \& Luc.

not terminating in a spine or style.

* A stridulating-ridge developed.

Stridulating-ridge narrow, tuberculated. Ambulatory legs with the penultimate joints dilated and compressed, nearly smooth, with long marginal hairs............. Stridulating-ridge narrow, usually
tuberculated. O. arenaria (Catesby). 
with the penultimate joints tuberculated,not dilated and compressed, and without long marginal hairs. O. Kuhlii, De Haan.

Stridulating-ridge striated below. Ambulatory legs as in O. Kühlï.. O. africana, De Man.

** Chelipede without a stridulatingridge.

Penultimate joints of the second and third legs tuberculated, not dilated, and fringed with short stiff hair ................... O. cordimana, Desm.

I. Ocular pedicels prolonged beyond the cornea as a spine or style.

\section{Ocypoda ceratophthalma (Pallas). (Pl. XVII. figs. 1, 1a.)}

The series in the British-Museum collection includes specimens from the Mauritius (Dr. Leach and Lady F. Cole) ; Amirante Islands (Dr. R. W. Coppinger, H.M.S. ' Alert'); Port Natal ; Indian Ocean (Gen. Hardwicke); Philippine Islands (Cuming) ; Japan ; Celebes, Macassar, and Batjan (coll. Dr. Bleeker); Duke-of-York Island (Rev. G. Brown); Moreton Island, New South Wales; Friday Island, Torres Straits (Dr.R. W. Coppinger, H.M.S. 'Alert') ; Fiji Islands (H.M.S. 'Herald'); Samoa Islands (Rev. S. J. Whitmee) ; and Sandwich Islands ( $W . H$. Pease).

Two females are in the collection, labelled as having been received from St. Christopher's (Dr. J. E. Gray); but the locality certainly needs confirmation, since it would appear, from the details furnished by Kingsley (t.c. p. 180), that this species has not hitherto been recorded from localities beyond the limits of the Oriental region.

In this species the exterior orbital angles of the carapace are nearly right angles, or slightly acute and projecting laterally very slightly beyond the lateral margin of the carapace; the terminal styles of the ocular peduncles in the adult male usually project far beyond the outer orbital angles, but are sometimes much shorter, and in the young may be tuberculiform or even obsolete. The stridulating-ridge on the inner surface of the larger chelipede in the adult (both male and female) consists in its uppermost part of small tubercles, which widen out into small transverse secondary ridges; in the lower part the stridulating-ridge is usually very closely and finely striated, and is bordered externally (in the adult male at least) by a patch of fine close hair; there is an inferior patch of thick hair on the penultimate joints of the second and third ambulatory legs. 
M. De Man is, I think, right in regarding the Ocypoda Urvillei of Guérin (which Mr. Kingsley retains as distinct) as a synonym of this species. I may note that the greater length of the ocular styles is not exclusively, although generally characteristic of the male sex, since I have observed adult males from Duke-of-York Island in which they are much shorter, projecting little beyond the outer orbital angle.

In adult male specimens from the Sandwich Islands ( $W$. H. Pease), which otherwise do not differ from the typical $O$. ceratophthalma, the transverse striæ on the stridulating-ridges of the chelipedes are separated throughout by equal intervals, so that the ridge appears to be very evenly but coarsely striated throughout its length.

\section{Ocypoda cursor (Linn.).}

Of this species, which has been recorded from various Mediterranean localities and from the coast of Senegal, the Congo, Acra d'Elmina, and the Cape-Verds, and in which the carapace is broadest at the antero-lateral or exterior orb:tal angles, which are acute, the ocular styles short and terminated by a pencil of hairs, and the stridulating-ridge of the larger chelipede very finely striated, there are at present no adult examples in the Museum collection.

In a series of young specimens of small size from Syria (Dr. O. Staudinger), which may possibly be immature $O$. cursor, the eyes are distally rounded, without any indications of a terminal style, and the sides of the carapace straight for a short distance behind the antero-lateral angles, the stridulatingridge is very narrow and indistinct, but finely striated.

1 may refer to Savigny's figure of this species in his large work on Egypt for a representation of the characteristic peculiarities of the carapace and eyes *.

The deficiencies of the Museum collection as regards adult examples of $O$. cursor will doubtless be supplied whenever opportunity shall offer for the examination of the large series of 'Challenger' Brachyura, at present unpacked and awaiting transference to the galleries of the new Natural-History Museum, since Mr. Moseley expressly records the occurrence of this species (as Ocypoda ippeus) at St. Vincent, CapeVerds $\dagger$.

* 'Description de l'Egypte,' Atlas, Crustacés, pl. i. fig. 1.

+ 'Notes by a Naturalist on the 'Challenger,' pp. 48, 49 (1879, with a woodcut). 


\section{Ocypoda macrocera, Milne-Edwards. (Pl. XVII. figs. 2, $2 a, 2 b$.)}

Of this species, of which Mr. Kingsley had seen no specimens, there are in the British Museum but three males, one obtained at Pondicherry and two at the mouth of the Hoogly (Hon. East-India Co.). They are at once distinguishable from $O$. ceratophthalma, typical examples of which they resemble in the greatly elongated terminal styles of the ocular peduncles \&c., by the form of the fingers of the smaller chelipede, which are lamellate and dilated to the apices, which are broad and subtruncated; the dilatation, however, is much less than in $O$. Gaudichaudii. The lateral margins of the carapace are, moreover, more distinctly angulated than in that species and $O$. ceratophthalma.

The stridulating-ridge on the inner surface of the palm of the larger chelipede is rather broad, closely, finely, and evenly striated, and bordered externally with hair; the fingers subacute. The penultimate joints of the second and third legs are hairy on their inferior surface, as in O. ceratophthalma, of which species a larger series of examples might show $O$. macrocera to be merely a variety, though I could not venture to unite the two forms at present.

\section{Ocypoda segyptiaca, Gerstäcker. (Pl. XVÍI. figs. 3, 3 a.)}

This species, upon the distinctness of which from 0 . ceratophthalma I have already remarked *, is united by Mr. Kingsley, who follows Kossman, with $O$. ceratophthalma, but is retained as distinct by Dr. De Man (t. c. p. 247), who summarizes its principal specific characters. It is, in fact, easily distinguishable by the form of the carapace, which is arcuated and bulges out laterally behind the more or less rounded exterior orbital angle, by the finer, more crowded transverse striæ of the upper part of the stridulating-ridge on the chelipede of the male, and by the existence of a patch of thick hair on the penultimate joints of the second legs only, and not, as usual in $O$. ceratophthalma and allied species, on the penultimate joint of the third legs also. The terminal styles of the eye-peduncles are usually curved. It should be stated that Kingsley had seen no specimens of this species.

Specimens are in the British-Museum collection from Egypt (Sir J. G. Willinson), Red Sea, Gulf of Suez ( $R$. MacAndrew), Gulf of Akaba (Major Burton), El Tor

* Ann. \& Mag. Nat. Hist. ser. 5, ii. p. 409 (1878). 
(Major MacDonald), and others without special indication of locality.

Two much mutilated specimens from the Red Sea, designated by White $O$. Fabricii, are doubtless a less mature condition of this species, from adult examples of which they are only distinguished by their smaller size, the less obtuse angles of the carapace, and by the very short ocular styles (which now only exist in one specimen).

I have seen no specimens which I can refer with certainty to the Ocypoda Fabricii as characterized by Kingsley, which in the structure of the stridulating-ridge somewhat resembles $O$. platytarsis and also $O$. ceratophthalma, as described by the American author. May it not be the young of the latter species?

\section{Ocypoda rotundata, sp. n. (Pl. XVII. figs. 4, 4a.)}

I am obliged thus to designate an adult male of very large size (length of carapace $2 \frac{1}{12}$ inches, 53 millim.; greatest breadth $2 \frac{1}{3}$ inches, nearly 60 millim.), in which the carapace is very coarsely granulated, the granules much less crowded than in $O$. ceratophthalma and $O$. cegyptiaca, with the exterior orbital angles very broadly rounded, so that the anterolateral margins of the carapace sweep round in a continuous curve to the upper margin of the orbits, which curve is only slightly interrupted by a shallow notch at the point occupied by the projecting angle of the orbit in O. ceratophthalma. The terminal styles of the eye-peduncles are short, straight, not reaching to the lateral margins of the carapace. There are scarcely any indications of the upper part of the stridulating-ridge on the inner surface of the palm of the larger chelipede; the lower part of the stridulating-ridge is composed of a series of widely-separated secondary ridges; the palm itself is very massive, with a few scattered granules on its outer surface; the margins both of arm, wrist, and chela are armed with spinules or small tubercles; the merus joints of the ambulatory legs are armed with a strong tooth or spine at the distal ends of their upper margins; there exists, as in $O$. agyptiaca, a patch of hair on the inferior surface of the penultimate joint of the second legs only.

The specimen, which is much mutilated, is labelled "Dukhun, Col. Sykes" (coll. India Museum), and was probably obtained at some locality on the western coast of India.

The form of the carapace and of the stridulating-ridge serve to distinguish it from any specimen of the genus in the $\mathrm{Mu}$ seum collection; but upon the whole it most nearly resembles o. agyptiaca, and the distinctions may possibly be either ab- 
normal and due to the age and large size of the specimen, or characteristic of a well-marked local variety. More specimens are needed to decide this point with certainty.

6. Ocypoda platytarsis, Milne-Edwards.

(Pl. XVII. figs. 5, 5 a.)

This species is nearly allied to $O$. ceratophthalma, but is distinguished by the relatively broader carapace, with more strongly sinuated upper orbital margin, the exterior angle of which is not acute, by the form of the stridulating-ridge on the inner surface of the large chela, which consists in both sexes of a series of small tubercles which do not widen out into striæ and are not bordered by hair, and by the absence of hair from the under surfaces of the penultimate joints of the ambulatory legs in both sexes. The dactyli of the ambulatory legs are somewhat dilated in the adult.

There is in the British-Musenm collection an adult male from Madras and a small male without special locality (coll. EastIndia Museum), also an adult female without special locality (Gen. Hardwicke), a smaller male from the collection of the Hon. East-India Company, and a fine adult male and smaller mutilated example from Ceylon (Dr. J. Davy).

In some young specimens from Ceylon $(E . W . H$. Holdsworth) the ocular styles are small or rudimentary, or even (in the smallest examples) wholly deficient; and in these specimens the carapace is relatively narrower and the dactyli of the ambulatory legs slender and styliform, so that were it not for the existence of large specimens in the same phial the species could not be certainly identified.

7. Ocypoda Gaudichaudii, Milne-Edwards \& Lucas. (Pl. XVII. figs. 6, 6a.)

Of this species, which is at once distinguishable by the broad and squarely-truncate fingers both of the right and left chelipedes, there are in the British-Museum collection two males and a female from Panama (Bridges and Smithsonian Inst.), and a female from Esmeralda, Ecuador (Fraser) ; also an adult male from Chile (Rev. Dr. Hennah).

The antero-lateral angles of the carapace in these specimens are slightly acute and project laterally; the ocular styles are prolonged but little beyond them; and the stridulatingridge of the larger chela, alike in males and females, is narrow, consisting in its upper part of a row of granules or small tubercles, which widen out into close-set striæ in the lower portion. The ambulatory legs are granulated and rugose, but almost entirely destitute of hair. 
I have seen no specimens referable to the $O$. Ryderi, Kingsley (t. c. p. 183), from the coast of Natal, which is described as closely allied to the American O. arenaria, but distinguished by the existence of a minute terminal ocular spine and by having the ambulatory legs roughened by subspiniform granules. Unless it differ in the form of the stridulatingridge, I see no reason why it should not be a variety of Ocypoda ceratophthalma (Pallas).

\section{Eyes rounded at the distal extremity, not terminating in a spine or style.}

\section{Ocypoda arenaria (Catesby).}

$$
\text { (Pl. XVII. figs. 7, } 7 a, 7 \text { b.) }
$$

Specimens are in the collection of the British Museum from the eastern and southern coasts of the United States (Smithsonian Institution), Georgia (T. Say), Jamaica, St. Christopher's (Dr.J.E. Gray), Vera Cruz (F. Du Cane Godman), Pernambuco (W. Forbes), and Rio Janeiro (Dr. Cunningham), besides others without special indication of locality.

In all the specimens I have examined the carapace is more coarsely granulated on the hepatic and sides of the branchial regions than on the gastric and cardiac regions, the lateral (or exterior orbital) angles are acute and rather prominent. The stridulating-ridge on the inner surface of the palm of the larger chelipede consists in the adult (both male and female) of a series of tubercles, which do not lengthen out into ridges or striæ. The ambulatory legs are dilated and compressed, the dilatation being most marked in the merus and penultimate joints; and the penultimate and antepenultimate joints (and usually the merus) are clothed along their margins and partially on their inferior surfaces with long fulvous hairs.

In one adult male example from Georgia the stridulatingridge is nearly obsolete; it is represented merely by a few irregularly disposed tubercles.

There is in the British-Museum collection an adult female (unfortunately without chelipedes), obtained by purchase as from Japan with other Crustaceans undoubtedly Japanese, which closely resembles $O$. arenaria in the nearly smooth, dilated and compreśsed, and hairy ambulatory legs. Probably there is here some mistake regarding the locality at which the specimen was collected.

9. Ocypoda Kuhlii, De Haan.

(Pl. XVII. figs. 8, $8 a, 8$ b.)

This species, reference to which is not made in Mr. Kings- 
ley's revision of the genus, was only known by the very brief and insufficient diagnosis of its author until fully redescribed by Dr. De Man (t. c. p. 250), who records it only from Java and the Indian archipelago. In the typical form of this species the carapace is granulated more coarsely toward the sides than in the middle line, the antero-lateral (or exterior orbital) angles are acute and rather prominent, and the stridulating-ridge in the adult (both male and female) consists of a series of small tubercles, as in $O$. arenaria; but the ambulatory legs are never margined with hairs as in that species, and the penultimate joints are much less dilated and compressed and more coarsely granulated.

To this species are referred :- a series of rather small specimens from Thursday Island, Torres Straits (Dr. Coppinger, H.M.S. 'Alert') ; an adult male from Shark Bay, W. Australia (Surgeon Rayner, H.M.S. 'Herald'), and other adult examples collected during the same expedition and probably from the Australian seas, but without special indication of locality; also an adult female from Japan and small specimens from the New Hebrides ( $W . W y k e h a m$ Perry) and Sandwich Islands (W. H. Pease), and an adult female and smaller male from Madagascar (Rev. Deans Cowan and Dr. J. E. Gray).

In certain specimens, as (e.g.) in the adult female from Madagascar, the tubercles of the stridulating-ridge show a tendency to widen out into small secondary ridges. This specimen further resembles the following variety in having the carapace much more evenly granulated, the granulations on the gastric and cardiac regions being very nearly as coarse as on the sides of the branchial and the hepatic regions. In certain smaller specimens, as, for instance, in two from the New Hebrides, the antero-lateral angles of the carapace are much less prominent.

I can see no reason why the Ocypoda convexa of Quoy and Gaimard*, from Australia, should not be referred to this species or to $O$. cordimana. The original description does not state if there be a stridulating-ridge, although the words "chaque pince a deux rangs de petites granulations à son extrémité "may refer to this structure. In the figure the penultimate joints of the ambulatory legs of the first and second pairs are represented as fringed with short hairs on their anterior margins.

I consider the Ocypoda oocidentalis of Stimpson + (to which no reference is made by Mr. Kingsley), from California, Cape

* Voy. de l'Uranie, Zool. iii. p. 525, pl. lxxvii. fig. 9 (1824); Kingsley, t. c. p. 185 (1880).

$\dagger$ Ann. Lyc. Nat. Hist. New York, vii. p. 229 (1860).

Ann. \& Mag. N. Hist. Ser. 5. Vol. x. 
St. Lucas, as probably a variety of this species. Three specimens are in the British-Museum collection from Cape St. Lucas (Smithsonian Institution). They are distinguished from $O$. arenaria by being destitute of the long hair from the margins of the ambulatory legs, whose penultimate joints are less dilated than in 0 . arenaria, and by having the carapace very evenly granulated over the whole of its dorsal surface. 'This latter eharacter will also distinguish this variety from the typical condition of $O$. Kuhlii; yet, in the specimen from Madagascar above referred to, the granulations of the carapace are as even and regular as in the Californian examples. The penultimate joints of the ambulatory legs are smoother below and more thickly clothed with short thick lines than in adult Australian examples of $O$. Kuhlii; but a specimen from the New Hebrides resembles Stimpson's variety in these particulars. To illustrate the very different character of the hairs which clothe the ambulatory limbs in the two species, I have figured (fig. $8 b$ ) the under surface of the first ambulatory leg of one of the specimens designated $\mathrm{O}$. occidentalis in the $\mathrm{Mu}$ seum collection, and probably named by Dr. Stimpson, with which may be compared the drawing of the same limb of $O$. arenaria from one of Say's Georgian specimens (fig. 7 b). If (of which there is no evidence in the Museum collection) intermediate conditions occur connecting $O$. Kuhlii and $O$. africana with $O$. arenaria, the latter name, having priority, would have to be used for the species, which would have an almost cosmopolitan distribution throughout the warmer temperate and tropical seas of the globe.

\section{Ocypoda africana, De Man.}

I have seen no specimens of this species, which inhabits the West-African coast (Liberia to the Congo), and is described by $\mathrm{M}$. De Man as very nearly allied to $Q$. cordimana, but differing in the possession of a stridulating-ridge, in which it is allied to $O$. Kuhlii, typical specimens of which it further resembles in having the under surface of the penultimate joints of the second and third legs devoid of patches of hairs: It is distinguished from typical specimens of $O$. Kuhlii principally, it would seem, by the more evenly granulated carapace and the striated (not tuberculated) stridulating-ridge; but I have observed specimens of $O$. Kuhlii which approach it in both these particulars.

The linear tubercle of the ischium joint of the larger chelipede, specially mentioned by De Man, against which the stridulating-ridge impinges, exists more or less distinctly in all the species of Ocypoda I have examined except $O$. cordi- 
mana, where it is absent, as well as the stridulating-ridge itself.

Were it not for the locality of $O$. africana, I should have supposed this form to be a mere variety of $O$. Kuhlii, with which M. De Man does not even compare it.

With this species the Ocypoda hexagonura of Hilgendorf*, which also inhabits the coasts of Loango, Liberia, and Rufisque, is probably identical; in the specimens described by Hilgendorf the strix of the stridulating-ridge pass into small tubercles in the upper portion; the penultimate joint of the ambulatory legs is hairy only on its distal parts.

\section{Ocypoda cordimana, Desmarest. (Pl. XVII. figs. 9, $9 a$ ).}

Specimens are in the British-Museum collection from the Mauritius, Rodriguez (H. H. Slater) ; Seychelles, Amirante, and Providence Islands (Dr. Coppinger, H.M.S. 'Alert'); Indian Seas, Ceylon (E.W. H. Holdsworth) ; Koo Keang San (H.M.S. 'Samarang'); Borneo, Fiji Islands, Ovalau, Totoya (H.M.S. 'Herald') ; New Hebrides (Mr. MacGillivray); and others without special locality.

This species, as De Man has shown, is at once distinguishable from $O$. Kuhlii by the absence of a stridulating-ridge from the inner surface of the palm of the larger chelipede in both sexes. The carapace is quadrate, very slightly transverse and very convex, and is somewhat more coarsely granulated toward the sides than on the gastric and cardiac regions. The antero-lateral angle is acute and moderately prominent. The chelipedes are less elongated and usually more finely granulated than in $O . K u h l i i$; and the under surfaces of the penultimate joints of the second and third ambulatory legs are usually provided with a fringe of short thick hairs.

In the report on the Crustacea collected by the Transit-ofVenus expedition at Rodriguez $\dagger I$ confounded under the designation $O$. cordimana specimens both of this species and $O$. Kuhlii. The distinctive characters of the two species were indeed never known until indicated by Dr. De Man.

\section{EXPLANATION OF PLATE XVII.}

* The figures (unless otherwise noted) represent the exterior orbital angle and the stridulating-ridge on the inner surface of the palm of the larger chelipede in each species, and are drawn, of the natural size, from

* Sitz. Gesellsch. naturforsch. Freunde zu Berlin, 1882, p. 23.

$\dagger$ Phil. Trans. clxviii. p. 489 (1879). 
adult male examples. Some of the outlines of the orbits are drawn slightly foreshortened on account of the convexity of the dorsal surface of the carapace. The character of the stridulating-ridges will be better made out if examined with a lens.

Figs. 1, 1 a. Ocypoda ceratophthalma (Pallas).

Figs. 2, 2 a. O. macrocera, Milne-Edwards.

Fig. $2 b$. Outer view of smaller chela of the same species, showing the somewhat dilated fingers.

Figs. 3, 3 a. O. agyptiaca, Gerstäicker.

Figs. 4, 4a. O. rotundata, sp. n.

Figs. 5, 5 a. O. platytorsis, Milne-Edwards.

Figs. 6, 6a. O. Gaudichaudlii, Milne-Edwards and Lucas.

Figs. 7, 7 a. O. arenaria (Catesby).

Fig. 7 b. Under surface of part of first ambulatory leg of the same species, showing the long marginal hairs.

Figs. 8, 8 a. O. Kuhlii, De Haan.

$F i g .8$ b. Under surface of part of the first ambulatory leg (from a specimen from Cape St. Lucas designated by Stimpson O. occidentalis).

Figs. 9, 9 a. O. cordimana, Desmarest.

XLI.-Embryogeny of the Bryozoa; an Attempt at a General Theory of their Development, founded upon the Study of their Metamorphoses. By Dr. Jules BARRors.

[Concluded from p. 279.]

\section{Cyclostomata.}

My recent researches upon the Cyclostomata, which were undertaken specially with the object of studying the phenomena of the metamorphosis, were all carried on in the Mediterranean, which is so rich in various forms of Cyclostomata, and more particularly at Villafranca. The two principal types to which I have paid attention are the Frondiporæ and the Discoporæ; the former, remarkable for the large size of the larva, which is peculiarly well adapted for observation, and with which it is easy to obtain sections, are unfortunately difficult to obtain in great abundance. The latter are common at Villafranca about the wet dock : their larvæ are small, and only moderately well fitted for the study of the fixation; but they have the advantage of belonging to a type which closely approaches the type of the Chilostomata, and may serve perfectly as a means of comparing together the larvæ of these two great groups. Those of the Frondiporæ do not differ at all from the ordinary type that I have already described. 